Wiktoria Danilewicz-Prokorym

Uniwersytet $w$ Biatymstoku

Joanna Huzarska

Uniwersytet $w$ Biatymstoku

\title{
ODPOWIEDZIALNOŚĆ NA ZASADZIE SŁUSZNOŚCI A MIARKOWANIE ODSZKODOWANIA W ŚWIETLE ORZECZNICTWA I POGLĄDÓW DOKTRYNY
}

W literaturze przedmiotu wyróżnia się najczęściej trzy główne zasady odpowiedzialności odszkodowawczej: zasadę winy, ryzyka i słuszności. Niektórzy przedstawiciele nauki wskazują, że na podstawie unormowań odpowiedzialności odszkodowawczej można zidentyfikować następujące zasady odpowiedzialności: winy, bezprawności, ryzyka, absolutną i słuszności. ${ }^{1}$ Zdaniem M. Kalińskiego przedstawiona kolejność wyliczenia wiąże się (z wyjątkiem zasady słuszności) ze stopniem pewności indemnizacji, którą zapewnia oparcie odpowiedzialności na danej zasadzie. ${ }^{2}$ Wiodącą rolę w kodeksie cywilnym odgrywa zasada winy, która charakteryzuje się tym, że za szkodę odpowiada ten, czyje zawinione zachowanie ją spowodowało. W kodeksie cywilnym ${ }^{3}$ próżno jednak szukać definicji zachowania zawinionego. W piśmiennictwie przyjmuje się, że takie zachowanie musi być kwalifikowane jako bezprawne, czyli zakazane przez przepisy prawa, sprzeczne z zasadami współżycia społecznego bądź dobrymi obyczajami. Odwrotnie jest przy odpowiedzialności na zasadzie ryzyka. Odpowiedzialność jest tutaj niezależna od winy sprawcy czy bezprawności czynu i jest nałożona na sprawcę niejako z góry. W tym reżimie odpowiedzialności to na sprawcy ciąży obowiązek udowodnienia, że nie ponosi on winy za zdarzenie powodujące szkodę, a wynika ona z działania siły wyższej, wyłącznej winy poszkodowanego bądź wyłącznej winy osoby trzeciej, za którą nie ponosi on odpowiedzialności. Na kanwie tej odpowiedzialności ukształtował się zaostrzony system odpowiedzialności absolutnej, nazywanej też bezwzględną. Różni się on od odpowiedzialności na zasadzie ryzyka tym, że nie

M. Kaliński, Szkoda na mieniu i jej naprawienie, Warszawa 2014, s. 91.

Ibidem.

Ustawa z dnia 23 kwietnia 1964 r. - Kodeks cywilny (Dz.U. 1964 Nr 16, poz. 93 z późn. zm.), dalej k.c. 
przewiduje możliwości wyłączenia odpowiedzialności i nakłada na dłużnika bezwzględny obowiązek naprawienia szkody niekoniecznie przez niego wyrządzonej. ${ }^{4} \mathrm{~W}$ tym miejscu dochodzimy do systemu odpowiedzialności odszkodowawczej na zasadzie słuszności. Znajduje ona zastosowanie w sytuacji, gdy zasady współżycia społecznego przemawiają za przyznaniem odszkodowania, mimo że sprawcy nie można przypisać winy $\mathrm{w}$ chwili zdarzenia.

Nie można zaprzeczyć, że odpowiedzialność cywilna ma wypełniać funkcję kompensacyjną. Co więcej coraz częściej zdarza się, że poszkodowany w celu naprawienia szkody sięga poza bezpośredniego sprawcę zdarzenia, a mianowicie do osób, które na mocy ustawy bądź stosunku prawnego zostały zobowiązane do naprawienia szkody z tytułu sprawowania nienależytego nadzoru nad bezpieczeństwem ogólnym bądź poszczególną osobą. Czasem jednak odpowiedzialność takich osób jest wyłączona bądź nie wchodzi w grę. $Z$ tego też powodu należy pochylić się nad tematem odpowiedzialności odszkodowawczej na zasadzie słuszności. W pierwszej kolejności należy wskazać na zarys historyczny zasady słuszności, która miała swoje początki w starożytnej filozofii greckiej i była popularyzowana przez największych greckich filozofów - Sokratesa i Arystotelesa. Nie sposób tym samym nie zagłębić się w problematykę filozofii czy etyki. To bowiem Arystoteles, jako pierwszy, włożył między literę prawa materiał empiryczny w postaci zasad sprawiedliwości społecznej. Rozpowszechnił pogląd, że sama zasada winy nie wystarczy, a zasadę słuszności wyniósł nie tylko do rangi narzędzia modyfikacji twardego prawa, lecz jego łagodniejszej interpretacji. To stąd w językach aktów prawnych używa się zwrotów niedookreślonych, norm zostawiających luz decyzyjny czy tzw. „klauzul generalnych", które odsyłają do zasad współżycia społecznego, zasad moralnych. Nieostre pojęcia, takie jak „rażące niedbalstwo”, ,dobra wiara” czy „należyta staranność" zmuszają do patrzenia na dany przypadek przez pryzmat indywidualnych właściwości, tworząc szerokie możliwości interpretacyjne oraz porównawcze. Dzięki temu prawo odpowiada ludzkiemu poczuciu słuszności. Jednak „sztuka słuszności” wymaga odporności na naciski społeczne, poglądy opinii publicznej czy inne czasowe „trendy”. Prawo bowiem to nie sztuka emocji, to sztuka argumentacji. ${ }^{5}$

Współcześnie odpowiedzialność na zasadzie słuszności postrzegana jest jako zasada pomocnicza i uzupełniająca. Ma zastosowanie jedynie we wskazanych w kodeksie przypadkach, gdy brak jest podstaw do przypisania odpowiedzialności odszkodowawczej, jednak występują na tyle ważne powody, że przemawiają za kompensacją szkody. W polskim prawie odpowiedzialność cywilna na zasadzie słuszności występuje w ramach odpowiedzialności z tytułu czynów niedozwolonych opisanych w art. 417(2), 428 i 431 k.c. Część doktryny zdaje zaliczać się do kręgu wypadków objętych odpowiedzialnością, również przepisy dotyczące umow- 
nych ubezpieczeń majątkowych. Art. $827 \S 1$ k.c. wskazuje, że w razie rażącego niedbalstwa ubezpieczającego odszkodowanie z tytułu ubezpieczenia nie należy się, chyba że umowa lub ogólne warunki ubezpieczenia stanowią inaczej lub zapłata odszkodowania odpowiada w danych okolicznościach względom słuszności. Jednak przedstawiciele odmiennego poglądu stawiają w tym miejscu pytanie, czy nie jest to jedynie przesłanka obowiązku naprawienia szkody, a nie zasada odpowiedzialności. Z uwagi na charakter przepisów określających tę odpowiedzialność wymagają one ścisłej wykładni. Wydaje się, że najpopularniejszym obszarem zastosowania odpowiedzialności odszkodowawczej na zasadzie słuszności są tzw. „zdarzenia medyczne" oraz szkody wyrządzone przez działanie organów władzy publicznej. ${ }^{6}$

Zasada słuszności znajduje również zastosowanie w sytuacji, gdy sprawca szkody jest niepoczytalny lub nie można mu przypisać odpowiedzialności ze względu na wiek, a okoliczności czynią niemożliwym uzyskanie należnego odszkodowania od jego opiekunów (art. 428 k.c.). Cechą łączącą wszystkie przypadki odpowiedzialności na zasadzie słuszności jest to, że orzeczenie przez Sąd obowiązku naprawienia szkody na podmiot odpowiedzialny jest fakultatywne. Oznacza to, że w każdym wypadku zależeć będzie od uznania Sądu, po przeanalizowaniu okoliczności danej sprawy. Wówczas, gdy Sąd dojdzie do wniosku, że jest to usprawiedliwione zasadami współżycia społecznego, może zasądzić należne odszkodowanie od bezpośredniego sprawcy szkody. ${ }^{7}$

$\mathrm{Na}$ podstawie analizy poglądów dotychczas wyrażonych $\mathrm{w}$ doktrynie oraz orzecznictwa, problem odpowiedzialności osób małoletnich i niepoczytalnych w chwili wyrządzenia szkody daje szerokie pole do dyskusji. Nie sposób nie zauważyć w tym miejscu powiązania pomiędzy artykułem warunkującym odpowiedzialność - art. 427 k.c. a artykułem 428 k.c. ${ }^{8}$ określającym odpowiedzialność w szczególnych okolicznościach. Z porównania tych przepisów wynika, że odpowiedzialność na zasadzie słuszności jest uzasadniona w następujących wypadkach: 1) nadzór nie został ustanowiony mimo istnienia ku temu przesłanek, 2) brak przesłanek do ustanowienia nadzoru, 3) osoba zobowiązana do nadzoru uchyliła się od odpowiedzialności, 4) nie można ustalić miejsca zamieszkania osoby zobowiązanej do nadzoru, 5) nie można uzyskać odszkodowania od osoby zobowiązanej do nadzoru, ze względu na jej sytuację majątkową, bądź odszkodowanie jest niepełne. Należy zaznaczyć, że nie jest konieczne, aby bezpośredni sprawca czynu w chwili jego popełnienia pozostawał pod nadzorem. ${ }^{9} \mathrm{Z}$ jednej strony $\mathrm{w}$ doktrynie przyjmuje się, że art. 428 k.c. ${ }^{10}$ znajdzie zastosowanie tylko wówczas, gdy przyczyną wyłączenia winy sprawcy szkody była jedynie jego nieletniość bądź niepoczytalność. Jed-

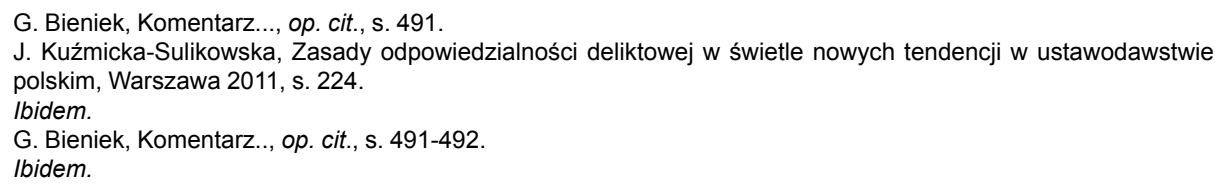


nak z drugiej strony w wyroku z dnia 9 marca 1963 r. Sąd Najwyższy przełamuje taki pogląd i stwierdza, że skoro „odpowiedzialność za wyrządzoną szkodę na zasadzie słuszności ma zastosowanie do sprawcy pozostającego pod władzą rodzicielską lub kuratelą, któremu z powodu wieku albo stanu psychicznego lub cielesnego winy przypisać nie można, to tym bardziej może ona mieć zastosowanie do takiego sprawcy, którego zwykły stan psychiczny nadzoru nie uzasadnia, lecz który może w wyjątkowych okolicznościach ulec zakłóceniu czynności psychicznych w stopniu wyłączającym jego winę". ${ }^{11} \mathrm{Z}$ całą pewnością jednak odpowiedzialność na podstawie art. 428 k.c. nie powstanie, gdy wyłączona jest bezprawność działania małoletniego lub niepoczytalnego bądź nie można ustalić związku przyczynowego między czynem a szkodą. Nie można też rozszerzyć tej odpowiedzialności na wypadki odpowiedzialności na zasadzie ryzyka.

Jedną z grup osób, od których mimo braku możliwości przypisania winy można domagać się należnego odszkodowania, są osoby małoletnie. Problem jest o tyle ważny i aktualny, że coraz częściej mamy do czynienia z odpowiedzialnością rodziców za nienależyte sprawowanie nadzoru nad dziećmi. Wydaje się, że wynika to z pozostawiania małoletnim coraz większego marginesu swobody i szeroko pojętej nauki samodzielności od najmłodszych lat. Nie da się ukryć, że metody wychowawcze, na przestrzeni lat, uległy zmianom. Należy zanotować również wzrost zagrożeń i niebezpieczeństw związanych z tą ewolucją. Stąd rodzą się pytania: „w jakim zakresie rodzic powinien odpowiadać za dziecko?”, ,czy pozostawiając dziecku większy margines swobody sami bierzemy odpowiedzialność za jego postępowanie?”. Do rozwiązania tego problemu należy podejść racjonalnie. Nie można wymagać od rodziców nieograniczonej odpowiedzialności za każde zachowanie dziecka, bowiem byłoby to nierealne. Niewykonalne jest nadzorowanie każdego kroku dziecka, rozłożenie nad nim „parasola ochronnego” i trzymanie z dala od innych osób. Granice odpowiedzialności winny uwzględniać faktyczne możliwości nadzorujących. Domniemanie z art. 427 k.c. nie może dotyczyć całej sfery wychowania, gdyż stałoby się praktycznie niewzruszalne. Powinno dotyczyć tych zaniedbań wychowawczych, których można było uniknąć biorąc pod uwagę okoliczności wyrządzenia szkody, wiek małoletniego, motywy i jego sposób działania. Również zachowania małoletnich podejmowane $\mathrm{z}$ dostatecznym rozeznaniem, nawet $\mathrm{w}$ wypadku pozostawania pod nadzorem rodziców winny być wyłączone spod zakresu domniemania przewidzianego w art. 427 k.c. Wyłączanie kolejno poszczególnych okoliczności i łagodzenie odpowiedzialności nadzorujących na zasadzie winy jest może racjonalne, ale bez wątpienia czyni utrudnionym uzyskanie odszkodowania. W tej sytuacji przedstawiciele doktryny opowiadają się za radykalną zmianą systemu odpowiedzialności w przypadku winy w nadzorze i postulują nałożenie na rodziców odpowiedzialnopoz. 38. 
ści z tytułu sprawowania nadzoru na zasadzie ryzyka. Miałaby ona jednak złagodzony charakter, podobny do odpowiedzialności zwierzchnika opisanej w art. 430 k.c. Wtedy do odpowiedzialności nadzorującego wystarczające byłoby bezprawne zachowanie małoletniego. Istniałyby jednak okoliczności wyłączające odpowiedzialność, takie jak siła wyższa, wyłączna wina poszkodowanego albo osoby trzecie, za którą nadzorujący nie ponosi odpowiedzialności. Dotychczasowe propozycje nowelizacji kodeksu cywilnego zakładają również uzależnienie typu reżimu odpowiedzialności od wieku małoletniego. I tak przykładowo nadzorujący odpowiedzialny za dzieci poniżej lat 7 ponosiłby odpowiedzialność na zasadzie ryzyka w sytuacji, gdy zachowanie małoletniego można ocenić jako bezprawne. W przypadku dzieci między 8. a 13. rokiem życia, aby przypisać odpowiedzialność nadzorującego, oprócz bezprawności poszkodowany będzie musiał wykazać zawinienie czynu małoletniego. Za osoby między 13. a 18. rokiem życia pozostające pod pieczą rodziców bądź opiekunów będą, podobnie jak dotychczas, ponosić odpowiedzialność nadzorujący, ale tylko w wypadku wykazania winy małoletniego. Granica wieku wynika ze stopnia rozwoju i rozeznania małoletniego. Mimo wskazania sztywnych ram wiekowych, każdy przypadek należy oceniać na podstawie towarzyszących mu okoliczności. Na tym tle szczególnie istotną wydaje się również kwestia tego, czy odpowiedzialność rodziców na zasadzie ryzyka winna mieć charakter samodzielny czy subsydiarny. Wydaje się być uzasadniony pogląd, przewidujący odpowiedzialność rodziców w przypadku wyrządzenia szkody przez małoletniego do lat 13 i przyjęcie odpowiedzialności subsydiarnej w stosunku do dzieci między 13. a 18. rokiem życia. W świetle zaproponowanych zmian wina małoletniego do lat 13 jest bowiem domniemana, natomiast sprawcy powyżej 13 lat winę należy udowodnić. ${ }^{12}$ Taki podział ma swoje uzasadnienie w możliwości wyegzekwowania świadczenia bezpośrednio od sprawcy szkody. Odpowiedzialność subsydiarna byłaby uruchamiana dopiero w sytuacji stwierdzenia bezskuteczności egzekucji od małoletniego. Nie każdy bowiem 17-latek uzyskuje wynagrodzenie lub ma wystarczający majątek do pokrycia równowartości bądź nawet części wyrządzonej szkody. Dlatego, mimo faktycznego zawinienia bezpośredniego sprawcy, odpowiedzialność nadzorujących winna mieć charakter subsydiarny. Przyjęcie takiego charakteru odpowiedzialności jest na chwilę obecną dyskusyjne, z uwagi na brak szerszego poparcia w doktrynie. Jednak biorąc pod uwagę tempo rozwoju społeczeństwa, w którym funkcjonujemy próba podjęcia przedmiotowego problemu zdaje się być zasadna i winna wzbudzić zainteresowanie teoretyków prawa.

W świetle przedmiotowego artykułu należy zauważyć, że kierunków przyszłych nowelizacji odpowiedzialności deliktowej jest wiele. Same propozycje zmian w zakresie klauzul generalnych i zasad sprawiedliwości społecznej napotykają tyle rozbieżności, że droga do osiągnięcia konsensusu wydaje się być wciąż daleka. 
Szczególnie, że niektóre poglądy pozostają w zupełnej sprzeczności. Przykładowo przedstawiciele jednego z nurtów opowiadają się za zupełnym usunięciem z regulacji ustawowych klauzuli zasad współżycia społecznego. Podczas gdy druga grupa opowiada się za wprowadzeniem do kodeksu nowej instytucji, a mianowicie klauzuli rozsądku i słuszności. Jeszcze inni stoją na stanowisku, że zasady współżycia społecznego można zastąpić szerokim pojęciem dobrej wiary i pozwoli to na ujednolicenie pojęć. Nie można jednak tracić z pola widzenia roli, jaką mają pełnić zasady współżycia społecznego i co doskonale przedstawia się na problemie odpowiedzialności odszkodowawczej na zasadzie słuszności. Otóż celem odwołania się przez ustawodawcę do zasad słuszności jest zachowanie równowagi pomiędzy generalną literą prawa a indywidualnym charakterem danego przypadku. ${ }^{13}$

Odpowiedzialność odszkodowawcza na zasadzie słuszności zakłada, że jeżeli roszczenie poszkodowanego jest uzasadnione zasadami współżycia społecznego, ma on prawo domagania się od sprawcy naprawienia szkody. ,ZZasady współżycia społecznego są bowiem kryterium oceny każdego zachowania się i według tego kryterium ocenia się realizację praw podmiotowych, chyba że z uwagi na szczególne uregulowanie stosowanie art. 5 k.c. nie może wchodzić w grę" (wyrok Sądu Najwyższego - Izba Cywilna i Administracyjna z dnia 6 kwietnia 1988 r. sygn. akt I CR 54/88; postanowienie Sądu Najwyższego - Izba Cywilna z dnia 7 stycznia 1972 r. sygn. akt III CZP 73/71). ${ }^{14}$ Przy miarkowaniu należnego odszkodowania brane jest wówczas pod uwagę porównanie stanu majątkowego sprawcy szkody i osoby domagającej się odszkodowania. Przez porównanie majątków należy rozumieć taką sytuację, gdy sprawca szkody ma majątek (nawet znacznej wartości, wobec tego ma z czego pokryć szkodę), natomiast poszkodowany takim majątkiem nie dysponuje (albo nie dysponuje żadnym majątkiem). Szczególnie, gdy to wyrządzenie szkody spowodowało znaczny uszczerbek w jego dobrach materialnych lub spowodowało utratę możliwości zarobkowania. ${ }^{15}$ Ponadto $\mathrm{w}$ doktrynie przyjmuje się za konieczne uwzględnienie również innych okoliczności, takich jak zdolności zarobkowe sprawcy i poszkodowanego, stan rodzinny, wiek, rodzaj naruszonego dobra i rozmiar szkody, a także stopień przyczynienia się poszkodowanego. ${ }^{16}$ Wskazując na powyższe należy stwierdzić, że katalog okoliczności ma w tym wypadku charakter otwarty. Ocena okoliczności będzie uzależniona od danego stanu faktycznego. O tym, czy w danych okolicznościach poszkodowanemu należy się częściowe czy całkowite naprawienie szkody należy rozstrzygań na tle konkretnego przypadku. Nie sprecyzowano bowiem w ustawie, kiedy konkretnie zasady współżycia spo-

J. Kuźmicka-Sulikowska, Zasady odpowiedzialności, op. cit., s. 227.

Wyrok Sądu Najwyższego - Izba Cywilna i Administracyjna z dnia 6 kwietnia 1988 r. I CR 54/88 Nowe Prawo 1988/10-12, s. 220; postanowienie Sądu Najwyższego - Izba Cywilna z dnia 7 stycznia 1972 r. III CZP 73/71 (LexPolonica $\mathrm{nr}$ 322314).

J. Kuźmicka-Sulikowska, Zasady odpowiedzialności..., op. cit., s. 221.

W. Dubis, (w:) E. Gniewek, Komentarz, Warszawa 2008, P. Machnikowski, (w:) System prawa prywatnego, t. 6 , s. 484 . 
łecznego uzasadniają naprawienie szkody w całości, a kiedy nie. Nie można więc wykluczyć, że odszkodowanie będzie równe rozmiarowi szkody (wyrok Sądu Najwyższego z dnia 16 lutego 1981 r., sygn. akt IV PR 22/81). ${ }^{17}$ Kwestia miarkowania odszkodowania należnego na podstawie art. 428 k.c. może być również rozpatrywana w nawiązaniu do kryteriów obniżenia odszkodowania na podstawie art. 362 k.c. Jak bowiem wynika z najnowszego orzecznictwa Sądu Najwyższego: „do obniżenia na podstawie art. 362 k.c. odszkodowania należnego małoletniemu, który ze względu na wiek nie ponosi odpowiedzialności, można - gdy wymagają tego zasady współżycia społecznego - stosować przez analogię art. 428 kc" (wyrok Sądu Najwyższego z dnia 19 marca 2014 r., sygn. akt I CSK 295/13)..$^{18}$ Za takim rozwiązaniem przemawiać może podobieństwo objętych tymi przepisami regulacji wyrażające się w obu przypadkach częściowym naprawieniem szkody, u których podstaw leży zasada słuszności. Z przedstawionego w sprawie stanu faktycznego wynika, że małoletnia lat 11 przechodząc przez jezdnię w miejscu niedozwolonym uległa wypadkowi komunikacyjnemu - została potrącona przez motocykl. Prowadzący pojazd w znaczny sposób przyczynił się do powstania szkody jadąc z prędkością $97 \mathrm{~km} / \mathrm{h}$, tj. o $47 \mathrm{~km} / \mathrm{h}$ większą niż dopuszczalna w tym miejscu. Ponadto poruszał się niewłaściwym pasem jezdni, nie przestrzegając przy tym zasad ruchu drogowego. Małoletnia odniosła liczne złamania i stłuczenia. Została poddana szeregowi operacji i zabiegów. Obecnie chodzi samodzielnie, chociaż utyka na prawą nogę. Wymaga pomocy osób trzecich, a powrót do pełnej sprawności jest niemożliwy. Ponadto została wyizolowana ze środowiska rówieśniczego i rodzinnego. $Z$ tego tytułu małoletnia domagała się odszkodowania, zadośćuczynienia i renty. Sąd I instancji nie uwzględnił zarzutu pozwanego przyczynienia się przez małoletnią do powstania szkody. Uwzględniając wiek powódki i jej stopień rozeznania uznał, że nie można jej przypisać nieprawidłowego zachowania, w takim samym stopniu jak kierującemu motocyklem. Na skutek apelacji Sąd Apelacyjny zmienił zaskarżony wyrok i przyjął, że małoletnia przyczyniła się do powstania szkody w $20 \%$. W ocenie Sądu 11-letnia dziewczynka miała świadomość swojego nagannego zachowania oraz grożącego jej niebezpieczeństwa. Na skutek złożonej skargi kasacyjnej Sąd Najwyższy zważył, iż ,, fakt, że z powodu wieku poszkodowanemu nie można przypisać winy, nie wyłącza możliwości kwalifikowania jego zachowania pod kątem nieprawidłowości i to w znaczeniu subiektywnym, uwzględniającego przy tym różną, zależną od wieku, możliwość rozeznania, zdolność oceny i analizy sytuacji przez poszkodowanego". O tym, czy obowiązek naprawienia szkody powinien zostać zmniejszony ze względu na przyczynienie się poszkodowanego, decyduje sąd według własnej oceny $\mathrm{i}$ jest to jego uprawnienie. Formuła przyjęta w art. 362 k.c. określa przyczynienie się

17 Wyrok Sądu Najwyższego - Izba Pracy i Ubezpieczeń Społecznych z dnia 16 lutego 1981 r., sygn. akt IV PR 22/81, Lex nr 14574.

18 Wyrok Sądu Najwyższego - Izba Cywilna z dnia 19 marca 2014 r., sygn. akt I CSK 295/13, Biuletyn Sądu Najwyższego $2014 / 7$. 
poszkodowanego oraz kryteria zmniejszenia odszkodowania. Aby jednak sprecyzować obie te przesłanki, koniecznym jest ustalenie, kiedy poszkodowany przyczynił się do powstania lub zwiększenia szkody. Zarówno w judykaturze, jak i orzecznictwie ukształtowały się cztery wiodące poglądy. Pierwszy z nich przemawia za tym, że przyczynienie się ma miejsce wówczas, gdy między szkodą a zachowaniem poszkodowanego zachodzi adekwatny związek przyczynowy. Kolejne koncepcje wymagają kauzalnego związku przyczynowego oraz bezprawności zachowania poszkodowanego, ewentualnie jego obiektywnej nieprawidłowości. Czwarta koncepcja do zmniejszenia odszkodowania wymaga oprócz związku przyczynowego, również winy po stronie poszkodowanego. ${ }^{19}$

Jak wynika z przywołanego już orzeczenia Sądu Najwyższego, sięgnięcie przez sąd do uprawnienia zmniejszenia obowiązku naprawienia szkody na podstawie art. 362 k.c. może pozostawać w sprzeczności z zasadami współżycia społecznego. W wyroku Sądu Najwyższego - Izby Cywilnej z dnia 3 sierpnia 2006 r., przyjęto, że „zachowanie się małoletniego poszkodowanego, stanowiące odrębną, konkurencyjną współprzyczynę szkody w stosunku do zdarzenia przypisywanego osobie ponoszącej odpowiedzialność za szkodę na zasadzie ryzyka, podlega ocenie w kategoriach przyczynienia się także wtedy, gdy poszkodowanemu z powodu wieku winy przypisać nie można”. Dalej Sąd zważył jednak, że „zmniejszenie obowiązku naprawienia szkody pomimo przyczynienia się poszkodowanego może pozostawać w sprzeczności z zasadami współżycia społecznego". W ocenie Sądu przyczynienie się należy oceniać w zależności od podstawy odpowiedzialności. I tak w sytuacji, gdy odpowiedzialność sprawcy oparta jest na zasadzie winy, to bez winy po stronie poszkodowanego nie można przyjmować, że doszło do jego przyczynienia się w rozumieniu art. 362 k.c. Tym samym do powstania szkody nie może przyczynić się osoba, której z powodu wieku albo stanu psychicznego winy przypisać nie można. Jak wskazano powyżej inaczej ma się rzecz, jeżeli odpowiedzialność za szkodę opiera się na zasadzie ryzyka.

W doktrynie przyjmuje się również, że w przypadku wyrządzenia przez sprawcę krzywdy, organ orzekający może na podstawie art. 428 k.c. zasądzić stosowne zadośćuczynienie. Punkt sporny stanowi jedynie ochrona dóbr osobistych niewymienionych w art. 445 k.c., ale objętych ochroną przez art. 448 k.c. (np. cześć, tajemnica korespondencji). W tym wypadku należy przychylić się do poglądu reprezentowanego przez większość doktryny i uznać, że stanowi on samodzielną podstawę prawną dochodzenia roszczeń, a co za tym idzie domaganie się naprawienia szkody niemajątkowej będzie wyłączone. ${ }^{20}$

Na marginesie tylko należy podkreślić, że to czy zasady współżycia społecznego wymagają naprawienia szkody na podstawie art. 428 k.c. ocenia się według

19 M. Kaliński, Szkoda..., op. cit., s. 542.

20 A. Olejniczak (red.), System..., op. cit., s. 508. 
stanu rzeczy z chwili wyrokowania. Jak wynika z wyroku Sądu Najwyższego z dnia 25 kwietnia 1969 r. wydanego w sprawie I CR 92/69: „Okoliczności, dzięki którym przyznanie poszkodowanemu odszkodowania odpowiadałoby względom słuszności, spośród których w przepisie art. 143 kz (obecnie art. 428 k.c.) wymieniono dyspozycję majątków poszkodowanego i sprawcy, muszą istnieć w czasie wyrokowania. Wynika to tak ze sformułowania przepisu, w którym hipotezy odniesiono do teraźniejszości, jak również z zasady, że podstawą wyrokowania jest stan rzeczy" ${ }^{21}$

Dążenie do bezpieczeństwa prawnego i pewności obrotu wymaga stanowienia precyzyjnych i skrupulatnych reguł zawartych w dokładnie opracowanych przepisach prawa. Jednak surowa litera prawa winna być oceniana również w kontekście znanej premii ius est ars boni et aequi. Paremią tą posłużyła się ostatnio także Izba Cywilna Sądu Najwyższego przy uzasadnieniu wyroku z dnia 14 listopada 2014 roku orzekającego, że Narodowy Fundusz Zdrowia nie może żądać od lekarza zwrotu pieniędzy za leki przepisane na błędnie wypisanej recepcie, jeśli pacjentowi były one rzeczywiście potrzebne. ${ }^{22}$ Sąd podniósł także brak podstaw do karania 90-letniego lekarza, kombatanta za sposób przepisywania recept dla siebie i najbliższej rodziny, w sytuacji, gdy Narodowy Fundusz Zdrowia nie wykazał istnienia szkody. ${ }^{23}$ Stąd wszelkie zmiany w kierunku szerzenia idei słuszności prawa wydają się być właściwymi i zasługują na pewną aprobatę. Warto też przypomnieć łacińską paremię: „Placuit in omnibus rebus praecipuam esse iustitiae aequitatisque quam stricti iuris rationem". ${ }^{24}$

21 Wyrok Sądu Najwyższego - Izba Cywilna i Administracyjna z dnia 25 kwietnia 1969 r. sygn. akt I CR 92/69, Biuletyn Informacyjny Sądu Najwyższego 1969/9, poz. 145.

Wyrok Sądu Najwyższego - Izba Cywilna z dnia 14 listopada 2014 roku, sygn, akt: I CSK 633/14, niepubl. http://wyborcza.pl/1,75478,16979485,Sad_Najwyzszy_NFZ_nie_moze_karac_lekarzy_za_byle.html „We wszystkich sprawach powinna mieć pierwszeństwo zasada sprawiedliwości i słusznóści nad ścisłą literą prawa". 


\section{LIABILITY BASED ON THE PRINCIPLE OF EQUITY AND MODERATING COMPENSATION IN THE LIGHT OF CASE LAW AND DOCTRINE VIEWS}

In the Polish system of civil law there are three main regimes of liability for damages formed. Liability with or without fault and liability based on the principle of equity. It happens more and more often that the aggrieved party in the purpose of compensating the damage reaches out beyond the direct perpetrator, namely to those who by act of law or on the basis of legal relationship, are obliged to repair the damage for inadequate supervision over general safety or a particular person. However, sometimes the responsibility of such people is excluded or is not an option. For that reason it is important to examine the topic of liability for damages based on the principle of equity which is applied merely to cases specified in the Code, that is Art. 417(2), 428 and 431 CC. Close attention should be drawn to liability for damages on the basis of Art. $428 \mathrm{CC}$. In this case, the liability is justified in the following cases: 1) supervisory is not established although there are indications for that, 2) lack of indications for establishing the supervisory, 3) a person obliged to supervise shirked his or her responsibility, 4) the residence of the person obliged to supervise cannot be established, 5) the compensation from the person obliged to supervise cannot be obtained due to his or her financial situation or the compensation is incomplete. If the claim of the injured party is justified by principles of social coexistence, he is entitled to demand compensation for the damage from the perpetrator. It is questionable, however, just how much compensation he can demand on the principle of equity. The determination of whether the obligation to compensate should be reduced because of contribution is made by the court in its own assessment and this is its power. In the light of the recent case law of the Supreme Court it is assumed that, "on the basis of Art. $362 \mathrm{CC}$, to reduce the compensation for a minor who is not liable due to age, it is possible to use Art. $428 \mathrm{CC}$ by analogy when it is demanded by the principles of social coexistence" (judgement of the Supreme Court of 19 March 2014, file ref. I CSK 295/13, Supreme Court Newsletter 2014/7).

Keywords: liability for damages, principle of equity, contributing of the aggrieved party, minor, principles of social coexistence 